\title{
Real-Life Evidence From Gallbladder Cancer: A Single Center Experience
}

\section{Safra Kesesi Kanserlerinde Tek Merkez Deneyimimiz}

\author{
Fatih Yıldız ${ }^{1}$, Emrah Eraslan¹, Ferit Aslan², Hüseyin Kanmaz ${ }^{3}$, Gülnihal Tufan¹, Umut Demirci', \\ Ömür Berna Öksüzoğlu ${ }^{1}$
}

${ }^{1}$ University of Health Sciences, Dr. A. Y. Ankara Oncology Hospital, Department of Medical Oncology, Ankara, Turkey

${ }^{2}$ Siirt State Hospital, Siiert, Turkey

${ }^{3}$ Balıkesir State Hospital, Balikesir, Turkey

Dergiye Ulaşma Tarihi:17/09/2018 Dergiye Kabul Tarihi:13/11/2018 Doi: 10.5505/aot.2018.40412

\section{ÖZET}

Giriş ve Amaç: Safra kesesi kanserleri nadir fakat ölümcül kanserlerdendir. Literatürde genellikle safra yolu kanserleri ile birlikte sınıflandırılmıştır. Bu yazıda safra kesesi kanserli hastaların klinik özelliklerini, adjuvan ve metastatik tedavi rejimleri ile sağ kalımlarını değerlendirmeyi amaçladık.

Yöntem ve Gereçler: Ocak 2011-Ekim 2017 tarihleri arasında Sağlık Bilimleri Üniversitesi, Dr. A. Y. Ankara Onkoloji Hastanesi Tıbbi Onkoloji Kliniği'ne safra kesesi tanısı ile başvuran hastalar retrospektif olarak değerlendirildi. Hastaların demografik özellikleri,cerrahi türleri, adjuvan ve metastatik tedavi rejimleri, tedavi yanıt durumları, genel sağkalım (OS) oranı ve hastalıksız sağ kalımları (DFS) değerlendirildi.

Bulgular: Çalışmaya dahil edilen 58 hastanın 34'ü (\%58.6) lokalize veya lokal ileri evredeydi. Metastatik olmayan hastaların 13'ü (\% 38.2) herhangi bir adjuvan tedavi almamıștı. Kemoradyoterapi en çok tercih edilen adjuvan tedavi seçeneğiydi (rezeke edilen hastaların\% 35.2'si). Adjuvan tedavi alan hastalarda median DFS ve OS, sirasiyla 24.8 (\% 95 CI: $1.5-48.1)$ ve 28 (\% 95 Cl: 20.6-35.4) ay iken adjuvan tedavi almayan hastalarda median DFS ve OS'ye ulaşılamad.

Tartışma ve Sonuç: Rezeke edilen safra kesesi kanserlerinde adjuvan tedavinin etkinliğini göstermek ve en uygun tedavi modalitesinin seçimi için prospektif, randomize kontrollü çalışmalara ihtiyaç vardır.

Anahtar Kelimeler: safra kesesi kanseri, safra yolu kanserleri, adjuvan tedavi

\begin{abstract}
Introduction: Gallbladder cancer (GBC) is an uncommon and highly fatal carcinoma. It is usually classified with biliary tract cancers in the literature. In this report we have planned to evaluate the clinical characteristics, adjuvant and metastatic treatment options and the survival of GBC patients.

Methods: A retrospective analysis of GBC patients treated in University of Health Sciences, Dr. A. Y. Ankara Oncology Hospital, Department of Medical Oncology between January 2011 and October 2017 was performed. The files of 58 patients with GBC were screened retrospectively. Treatment regimens, response rates, overall survival (OS) rate and disease-free survival (DFS) of the patients were evaluated.

Results: A total of 58 patients of whom 34 (58.6\%) were presented as non-metastatic stage. Thirteen $(38.2 \%)$ of non-metastatic patients did not receive any adjuvant treatment. Chemoradiotherapy was the most preferred adjuvant treatment option (35.2\% of resected patients). Median DFS and OS were 24.8 (95\% CI: 1.5 - 48.1) and 28 (\%95 Cl: 20.6-35.4) months respectively in patients who received adjuvant treatment however both were not reached in patients who did not receive any adjuvant treatment.
\end{abstract}

Discussion and Conclusion: In resected GBC, it is needed to prospective, randomized controlled trials for adjuvan treatment efficacy and choice of treatment modalities.

Keywords: gallbladder cancer, biliary tract cancers, adjuvant treatment

\section{INTRODUCTION}

Gallbladder cancer (GBC) is a rare and fatal tumor (1). The incidence of GBC in Turkey is $1.7 / 100,000$ and it is quite similar to USA (2). It ranks sixth among all gastrointestinal system cancers, but it is the most frequent tumour of all the biliary tract $(3,4)$. Most of the patients are diagnosed incidentally (5). The majority of patients have poor prognosis as they are in advanced stage at the time of diagnosis (4). The only curative treatment option of early stage GBC treatment is surgery. Despite R0 resection, the majority of patients develop metastases. The efficacy of adjuvant

Adressforcorrespondence: Uzm. Dr. Fatih Yıldız, University Of Health Sciences, Dr. A. Y. Ankara Oncology Hospital, Department Of Medical Oncology, Ankara, Turkey

e-mail: $\underline{\text { dr.fatihyildiz@ hotmail.com }}$

Available at www.actaoncologicaturcica.com

Copyright $\mathbb{C}$ Ankara Onkoloji Hastanesi 
chemotherapy and radiotherapy remains uncertain (6).

The GBC is usually grouped with biliary tract cancers, and therefore the clinical characteristics of the disease are not widely reported in the literature. In addition, the benefit of adjuvant treatment for resected GBC is not clear. Observation, adjuvant chemotherapy or chemoradiotherapy are the options reported in the guidelines because of insufficient number of randomized trials.

In this report, we have planned to evaluate the clinical characteristics, adjuvant and metastatic treatment options and the survival of GBC patients from a single research oncology center.

\section{MATERIALS and METHODS}

Between January 2011 and October 2017, a retrospective analysis of patients with GBC treated in University of Health Sciences, Dr. A. Y. Ankara Oncology Hospital, Department of Medical Oncology, was performed. The demographic characteristics of the patients (sex, age), smoking history, presence of cholelithiasis, date, and stage of diagnosis (localized, locally advanced, metastatic), type of surgery (cholecystectomy, extended liver resection), details of adjuvant and palliative therapy, date of last control and exitus status were evaluated from the hospital registry system, retrospectively.

The 7th edition of the AJCC TNM staging for GBC was used. Stage I/II was defined as localized, stage III as locally advanced and stage IV as metastatic disease.

SPSS version 24 was used for statistical analysis. DFS was defined as the time from diagnosis until the date of recurrence (local, regional or distant metastasis) or death. PFS was defined as the time from onset of chemotherapy to progression or death.OS was defined as the time from diagnosis to death. The Kaplan-Meier method was used to construct survival curves. Survival curves compared by log-rank test. The value of $\mathrm{p}$ $<0.005$ was statistically significant.

\section{RESULTS}

Of the $58 \mathrm{GBC}$ patients with a median age of 61 years (range:36-85), $45 \quad(77.6 \%)$ were female. The characteristics of patients are shown in table 1 .

Table 1: Patient Characteristics

\begin{tabular}{|c|c|c|}
\hline & $n: 58$ & $\%$ \\
\hline Age -years (Median) & 61 ( Range:36-85) & \\
\hline \multicolumn{3}{|l|}{ Sex } \\
\hline Female & 45 & 77.6 \\
\hline Male & 13 & 22.4 \\
\hline \multicolumn{3}{|l|}{ Smoking Status } \\
\hline Smoker & 15 & 25.8 \\
\hline Non-smoker & 43 & 74.1 \\
\hline \multicolumn{3}{|l|}{ Gallstones } \\
\hline Yes & 42 & 72.4 \\
\hline $\mathrm{No}$ & 16 & 27.6 \\
\hline \multicolumn{3}{|l|}{ Histology } \\
\hline Adenocarcinoma & 55 & 94.8 \\
\hline Adenosquamous carcinoma & 2 & 3.4 \\
\hline Ring cell carcinoma & 1 & 1.7 \\
\hline \multicolumn{3}{|l|}{ Stage } \\
\hline Localized (Stage I/II) & 18 & 31 \\
\hline Locally advanced (Stage III) & 16 & 27.6 \\
\hline Metastatic (Stage IV) & 24 & 41.4 \\
\hline
\end{tabular}

Adressforcorrespondence: Uzm. Dr. Fatih Yıldız, University Of Health Sciences, Dr. A. Y. Ankara Oncology Hospital, Department Of Medical Oncology, Ankara, Turkey 


\begin{tabular}{|l|c|c|}
\hline \multicolumn{1}{|c|}{ Surgery } & & \\
\hline Cholecystectomy & $10 / 34$ & 29.4 \\
\hline Extended hepatic resection & $24 / 34$ & 70.5 \\
\hline \multicolumn{1}{|c|}{ Adjuvant treatment } & & \\
\hline \multicolumn{1}{|c|}{ Chemoradiotherapy } & $12 / 34$ & 35.2 \\
\hline Chemotherapy & $5 / 34$ & 14.7 \\
\hline Radiotherapy & $4 / 34$ & 11.7 \\
\hline No treatment & $13 / 34$ & 38.2 \\
\hline \multicolumn{1}{|c|}{ Adjuvant treatment } & & 50.0 \\
\hline Stage I/II & $9 / 18$ & 75.0 \\
\hline Stage III & $12 / 16$ & \\
\hline
\end{tabular}

The majority of early-stage patients were diagnosed incidentally (82.3\%). All localized stage patients (n:18) were completely resected (R0) and only two in 16 locally advanced stage patients were R1 resected (12\%). Extended hepatic resection was performed in $70.4 \%$ of non-metastatic patients.

All of non-metastatic patients had ECOG performance score 1 and half of metastatic patients had ECOG performance score 2. Half of the patients had at least one comorbid disease.

Thirteen of non-metastatic patients did not receive any postoperative treatment. Nine (69\%) of the patients who did not receive postoperative treatment had early stage disease. For the 21 patients who received postoperative treatment, 12 of them had stage III disease and 10 of them were lymph node positive. Chemoradiotherapy was the most preferred adjuvant treatment option (35.2\% of resected patients). All of the patients in the chemoradiotherapy group were administered 5fluorouracil based chemotherapy and radiation target volume was 45 Gy at $1.8 \mathrm{~Gy} /$ fraction. Cholecystectomy was performed $29.4 \%$ of adjuvant treatment group and extended hepatic surgery was performed $38.2 \%$ of non-adjuvant treatment group.

The duration of median follow-up of nonmetastatic patients was 23.7 months. Median DFS was 24.8 months (95\% CI: 1.548.1) in patients who received postoperative treatment and was not reached in patients who did not receive any postoperative treatment (Fig.1; p=0.103). Two-year DFS was $42.2 \%$ for patients who received postoperative treatment, and $57.1 \%$ for patients who did not receive postoperative treatment.

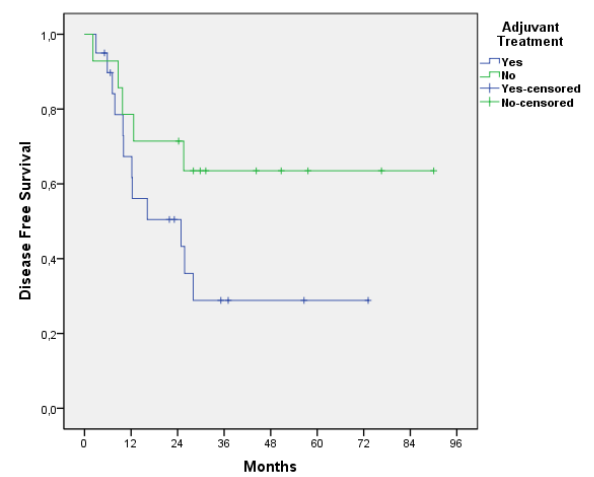

Fig.1: Disease Free Survival For Adjuvant Treatment in Resected Patients $(n=34)$

In the metastatic stage, $80 \%$ of the patients received at least one line of chemotherapy however $25 \%$ of patients underwent secondline treatment. Cisplatin/gemcitabine combination was the most preferred regimen in the first-line treatment of choice. Median PFS was 4.3 months (1-12.2) for the first-line chemotherapy.

The median follow-up was 15.3 months for the whole cohort (follow-up for metastatic disease 10.7 months versus non-metastatic disease 26.9 months) Median OS was 38.9 months (95\% CI: 9.8-68) for localized stage, 30.6 months (95\% CI: 18.7- 42.5) for locally advanced stage and 9.5 months (95\% CI: 513.9) for metastatic patients. There was no difference between localized and locally advance stages in terms of OS (p:0.68). Overall survival of the metastatic patients was worse than the other two groups (Fig 2; $\mathrm{p}<0.001)$ 


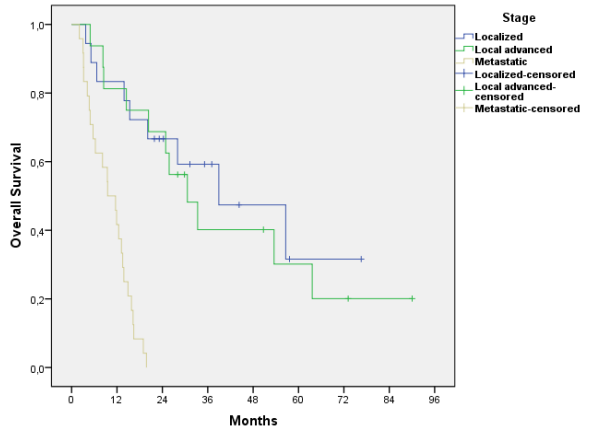

Fig. 2: Overall Survival For Localized, Locally Advanced and Metastatic Stage

Median OS was 28 months (\%95 Cl: 20.635.4) in patients who received postoperative treatment and was not reached in patients who did not receive postoperative treatment. Two year OS was 54\% (SE: 11.4\%) for patients who received postoperative treatment and $66.7 \%$ (SE: \%12.2) for patients who did not receive postoperative treatment (Fig 3; $\mathrm{p}: 0.097)$

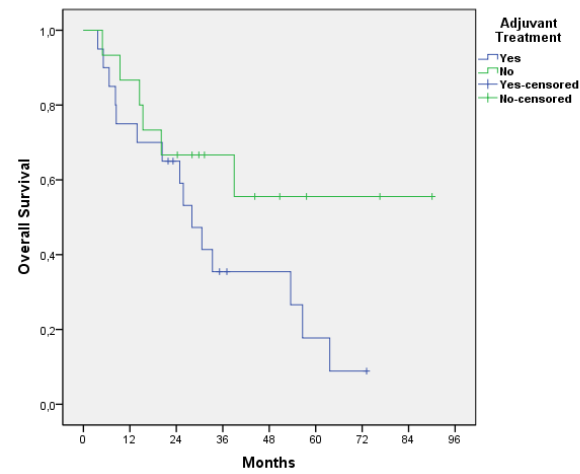

Fig.3 Comparison of overall survival according to adjuvan treatment

\section{DISCUSSION}

GBC is a rare and highly fatal carcinoma with different clinical features compared to other biliary tract cancers. In previous studies, GBC was generally assessed with biliary tract cancers. In addition, the benefit of adjuvant treatment in the resected GBC patients is not clear. There is no consensus on the use of adjuvant treatment for completely resected GBC. In this study, we have aimed to evaluate the single center experience with GBC retrospectively.

Similar to previous studies, the median age of 58 patients, of whom $77 \%$ were women, was $61(6,7)$.The rates of smoking $(76.9 \%$ for men,
$11.1 \%$ for women) and cholelithiasis $(72.4 \%)$ for GBC patients were found to be similar to the other studies which were conducted in different geographic areas $(8,9)$.

In this study, $29.4 \%$ of non-metastatic patients underwent cholecystectomy. These patients were not considered as candidates for reexploration by the surgeon. Due to different reasons (physician preference, co-morbidities), $38.2 \%$ of the completely resected patients did not receive adjuvant treatment $(50 \%$ (n: 9/18) of stage I-II patients and $25 \%$ (4/16) of stage III).

Median DFS was 24.8 months in patients who received postoperative treatment and was not reached in patients who did not receive postoperative treatment $(\mathrm{p}=0.103)$. Two-year OS was \%66.7 for adjuvant treatment group and was $\% 54$ for patients who did not receive postoperative treatment. Similarly, Duffy and colleagues found that poorer survival was obtained when adjuvant therapy was added to curative surgery (6).In another study adjuvant chemoradiation had a modest early survival advantage in locally advanced tumors; however, in the long term it was seen that this OS benefit did not continue (10). On the other hand, in the study of Park at al., adjuvant chemotherapy alone group showed a statistically significant improvement in OS compared to no adjuvant treatment or chemoradiotherapy groups (11).In a recent study of patients with gallbladder and biliary tract cancer, it was reported that adjuvant therapy improved DFS of about 3.2 months, but this result was not statistically significant. It was also reported that adjuvant treatment did not result in an OS benefit in this study (12).

In our study, for the non-adjuvant treatment population, despite reaching better DFS and OS outcomes numerically, it was not statistically significant. This may be explained by the low number of patients. Patients were stratified into adjuvant chemoradiotherapy, chemotherapy and radiotherapy arms, but none subgroup analysis were performed due to small number of patients. However, patients who received adjuvant treatment had higher relapse risk than patients who did not receive adjuvant treatment. Additionally, extended hepatic resection ratio was not similar in adjuvant treatment and non-adjuvant treatment group. 
In the metastatic group median PFS was 4.3 months and OS was 9.5 months. These results were similar to previous studies $(13,14)$.

The limitations of this study include retrospective study nature and the small number of patients for the evaluation of adjuvant treatment efficacy for the adjuvant treatment group who has a higher risk of relapse. However, it represents real world data. In conclusion, it is needed to prospective, randomized controlled trials for adjuvan treatment efficacy and choice of treatment modalities, in resected GBC.

\section{Conflict of interest: None}

\section{REFERENCES}

1. Nemunaitis JM, Brown-Glabeman U, Soares H et al. Gallbladder cancer: review of a rare orphan gastrointestinal cancer with a focus on populations of New Mexico. BMC Cancer. 2018; 18:665

2. Graphproduction: IARC(http://gco.iarc.fr/today), GLOBOCAN 2018

3. Shen HX, Song HW, $\mathrm{Xu}$ XJ et al. Clinical epidemiological survey of gallbladder carcinoma in northwestern China, 2009-2013: 2379 cases in 17 centers. Chronic Dis Transl Med. 2017; 3(1):60-66

4. Hamrick RE Jr, Liner FJ, Hastings PR, Cohn I Jr. Primary Carcinoma of the Gallbladder. Ann Surg. 1982;195(3):270-3

5. The Southern Surgeons Club. A prospective analysis of 1518 laparoscopic cholecystectomies. N Engl J Med. 1991;324(16):1073-8
6. Duffy A, Capanu M, Abou-Alfa GK et al. Gallbladder cancer (GBC): 10-year experience at Memorial Sloan-Kettering Cancer Centre (MSKCC).J Surg Oncol. 2008;98(7):485-9

7. Ostwal V, Swami R, Patkar S et al. Gemcitabinecisplatin (GC) as adjuvant chemotherapy in resected stage II and stage III gallbladder cancers (GBC): a potential way forward. Medical Oncology. 2018; 35:57

8. Yagyu K, Kikuchi S, Obata $\mathrm{Y}$ et al. Cigarette smoking, alcohol drinking and the risk of gallbladder cancer death: A prospective cohort study in Japan. Int. J. Cancer.2008;122(4),924-9

9. Shaffer EA. Gallbladder Cancer: Gastroenterology\&Hepatology. 2008; 4(10):737-741

10. Mantripragada KC, Hamid F, Shafqat H, Olszewski AJ. Adjuvant Therapy for Resected Gallbladder Cancer: Analysis of the National Cancer Data Base. J Natl Cancer Inst. 2016; 109(2)

11. Park HS, Lim JY, Yoon DS et al. Outcome of adjuvant therapy for gallbladder cancer. Oncology. 2010;79(3-4):168-73

12. Tugba Kos F, Aksoy S, Odabas $\mathrm{H}$ et al. Adjuvant therapy for gallbladder and bile duct cancers: retrospective comparative study. J BUON. 2011;16(3):464-8

13. Singh SK, Talwar R, Kannan Net al. Chemotherapy Compared with Best Supportive Care for Metastatic/Unresectable Gallbladder Cancer: a Nonrandomized Prospective Cohort Study.Indian J Surg Oncol. 2016;7(1):25-31

14. Kim BJ, Hyung J, Yoo C et al. Prognostic factors in patients with advanced biliary tract cancer treated with first-line gemcitabine plus cisplatin: retrospective analysis of 740 patients. Cancer Chemother Pharmacol. 2017;80(1):209-215 